\title{
“Doesn't Mary Have a Lovely Bottom?": Gender, Sexuality and Catholic Ideology in Father Ted
}

\section{Lisa McGonigle}

\section{Q OpenEdition \\ 1 Journals}

\section{Electronic version}

URL: http://journals.openedition.org/etudesirlandaises/2999

DOI: 10.4000/etudesirlandaises.2999

ISSN: 2259-8863

\section{Publisher}

Presses universitaires de Rennes

\section{Printed version}

Date of publication: 30 June 2012

Number of pages: 89-102

ISSN: 0183-973X

\section{Electronic reference}

Lisa McGonigle, " "Doesn't Mary Have a Lovely Bottom?": Gender, Sexuality and Catholic Ideology in Father Ted », Études irlandaises [Online], 37-1 | 2012, Online since 30 June 2014, connection on 19 April 2019. URL : http://journals.openedition.org/etudesirlandaises/2999; DOI : 10.4000/ etudesirlandaises.2999 


\title{
“Doesn't Mary Have a Lovely Bottom?": Gender, Sexuality and Catholic Ideology in Father Ted
}

\author{
Lisa McGonigle \\ University of Otago, New Zealand
}

Abstract

This paper examines discourses of gender and sexuality, and Irish socio-sexual formations, as they are lampooned in television sitcom Father Ted. It argues that despite the claims of writers Graham Linehan and Arthur Mathews that theirs is a depoliticized aesthetic, the series engages with and destabilises Catholic doctrine on issues such as homosexuality and contraceptives by making them the target of satire.

Keywords: Father Ted, sitcom, Catholicism, gender, sexuality, Sinead O'Connor, Monique Wittig, asceticism.

\section{Résumé}

Cet article se penche sur les questions du genre, de la sexualité et des aspects socio-sexuels irlandais telles qu'elles apparaissent dans la sitcom Father Ted. Il fait valoir que, malgré ce qu'en disent leurs auteurs Graham Linehan et Arthur Mathews, la série est aux prises avec (et déstabilise) la doctrine catholique sur des questions telles que l'homosexualité et la contraception, qui y deviennent des objets de satire.

Mots clé: Father Ted, sitcom, catholicisme, genre, sexualité, Sinead O'Connor, Monique Wittig, ascétisme.

The sitcom Father Ted, which originally aired from 1995 to 1998 on Britain's Channel 4, has gone on to achieve widespread popularity and cult status alike, taking top position in a 2008 poll of Ireland's favourite television programmes and a cohort of loyal "Tedheads" reenacting key moments from the series at an annual "Tedfest". Set on Craggy Island, a fictitious island located off the west coast of Ireland, Father Ted centres upon three priests Fathers Ted Crilly (Dermot Morgan), Jack Hackett (Frank Kelly) and Dougal Maguire (Ardal O'Hanlon) and their downtrodden housekeeper, Mrs Doyle (Pauline McLynn), who live together in the parochial house. However, although the programme emerged at

1. "AJ", "RTÉ Guide Top 100 TV Programmes", [http://www.lecraic.com/2008/10/01/irelands-top-100-tv-programmes-the-rte-guide-list], accessed 29/12/2011. 
a time when the Catholic Church in Ireland was embroiled in a series of scandals Mary Kenny describes how "on one Monday in November 1994, the three leading stories on RTÉ, the national television network, were the political repercussions following the Brendan Smyth case, the collapse and death of a Dublin priest in a homosexual sauna club, and the conviction of a Galway priest for a sexual assault on a young man, all in one news bulletin ${ }^{2 "}$. Arthur Mathews and Graham Linehan, the writers of the show, claim structural rather than political impetus in having chosen priests as comic personae for Father Ted, referencing the sitcom format in this regard. For example, they describe the clerical world as a closed community in which priests appear to all know one other, with such bonhomie enabling them to introduce and dispense of secondary characters with ease, Linehan also remarking that "one of the great things about priests is that they all dress the same. So you can take a concept, impose it on a priest and it becomes funny almost automatically ${ }^{3}$. The programme is thus populated by such figures as Father Finnegan, the Dancing Priest who claims "prayer isn't the only way to praise God, you know. And it keeps you fit as well" ("Think fast, Father Ted”, Season 2), Father Billy O’Dwyer whose DJ-ing has earned him the moniker "The Spinmaster" ("Think fast, Father Ted", Season 2) and the participants in the annual All-Priests Five-a-side Over Seventy-Fives Indoor Football Challenge, the star player of which "can walk up two flights of stairs unassisted. Only needs one nun to help him get out of a chair" ("Escape from Victory", Season 3). Linehan similarly remarks that "because of the mysterious thing religion is, you can make things up and spoof people... there's a reference to this disease that old priests get where they get very hairy, and because it's set in a vaguely mysterious world you might just believe that ${ }^{4 \prime}$. Rather than critiquing the clergy's traditional aloofness from the laity or interrogating the mysteries of faith, Father Ted exploits them for comic purpose.

With sitcom being an abbreviation, after all, of "situation comedy", a further structural advantage to the nature of the priesthood, Mathews and Linehan point out, is that none of the characters can easily extricate themselves from the set-up of the parochial house, thereby ensuring plenty of opportunity for situational setpieces. Ted is a would-be bon-vivant, aspiring to a life of celebrity and glamour, but he must remain exiled on the remote Craggy Island at the behest of his superiors due to his embezzlement of parochial funds, his tetchily repeated defence being that "the money was just resting in my account". His fellow clerics prove little consolation: the elderly Jack is lost in a perpetual alcoholic haze and Dougal

\footnotetext{
2. Mary Kenny, Goodbye to Catholic Ireland, London, Sinclair-Stevenson, 2000, p. 301

3. Ben Thompson, "In the Name of the Father", Independent, 23 April 1995. (Quoting Arthur Mathews and Graham Linehan, Father Ted: The Complete Scripts, Basingstoke, Macmillan, 1999, p.106)

4. Ibid.
} 
is largely theologically illiterate, variously asking Ted if he believes in the afterlife and offering the advice that "heaven and hell and everlasting life and all that type of thing - you're not meant to take it seriously" ("Good luck, Father Ted", Season 1). Mathews describes Ted's position as being "stuck with three people he had nothing in common with. All the best sitcoms are about thwarted ambition, chasing up blind alleys and being in a situation you don't want to be in", elsewhere citing Porridge and Steptoe and Son as classic sitcoms in this vein ${ }^{5}$.

Indeed, Linehan and Mathews repeatedly cite the influence of British sitcom upon Father Ted. When the surreality of the programme was compared to that of Flann O'Brien for example, there is no longer a west coast on Craggy Island, it just "drifted off... now it's just north, south and east" Mathews remarked that "it would be nice if we could say that we were influenced by some great Irish comic tradition... but really it's just Reggie Perrin, Fawlty Towers, The Young Ones stuff like that", elsewhere reiterating that "Ted would not have existed if it hadn't been for The Young Ones or Only Fools And Horses". Linehan also points to the structural similarities to Only Fools and Horses in that "you've got the guy who doesn't think he's stupid, but is, you've got the really stupid guy and you've got the old guy" and expressly describes Father Ted as "a sitcom in the British tradition although it was set in Ireland" ${ }^{7}$. Describing sitcom as "a form of programming which foregrounds its comic intent" in his formalist study of the genre, Brett Mills emphasises that "the sitcom's primary aim is to be funny". "Sitcom", he argues, "is only meaningful - and explicable as a genre - if its comic intent is understood; it is this which drives and defines it ${ }^{9 "}$. By situating and configuring Father Ted in specifically sitcom terms, Linehan and Mathews similarly seek to emphasise the primacy of the programme's humour.

Conversely, they also attempt to downplay interpretation of Ted as a vehicle for comment upon the Church by emphasising that the mode of the programme is one of comic inflation rather than social realism. Mathews describes "all the characters (apart from Ted) [as] rather extreme caricatures ${ }^{10}$ " and Linehan also remarks that "we didn't realize we were doing it at the time, but aside from Ted, each central character seems to be a parody of popular perceptions of the Irish. We were certainly sick of the clichés about Ireland - even the nice ones - so it

5. James Rampton, "The Point Is There Is No Point", Scotland on Sunday, 7 November 1999; James Thompson, "In the Name of the Father".

6. Ben Thompson, "In The Name Of The Father", Independent, 23 April 1995; Tom Lappin, "High Priests Of Comedy", Scotland on Sunday, 1 March 1998.

7. Deirde Falvey, "Fathers of Ted", Irish Times, 30 December 1995; Graham Linehan and Arthur Mathews, op. cit., p. 92.

8. Brett Mills, The Sitcom, Edinburgh, Edinburgh University Press, 2009, p. 49.

9. Ibid., p. 6

10. Arthur Mathews and Graham Linehan, op. cit., p. 340. 
felt good to bend and stretch those stereotypes until they became caricatures" ${ }^{11}$. Granted, it could be argued that the manner in which use is made in Father Ted of stereotypes and stock characters is congruent with how the programme operates as a sitcom, with Brett Mills observing of the sitcom genre that:

For representations to be successful and by successful, what is meant is easily understandable they must conform to and utilise normalised social conventions. For the sitcom, whose primary intention is the creation of comedy, "immediacy" is imperative, and to find a character immediately funny that character must be a recognisable type, a representative embodiment of a set of ideas or a manifestation of a cliché ${ }^{12}$.

Marxist critic Terry Eagleton, however, describes himself as a "champion of stereotypes on materialist grounds", arguing that "stereotypes are not always illusions $[\ldots]$ it would be surprising if people who have shared roughly the same cultural and material circumstances over long periods of time did not manifest some psychological traits in common ${ }^{13}$, and indeed, rather than the character traits and cultural norms which undergo caricaturisation and comic gigantism in Father Ted being rendered apolitical by dint of their stereotypicality, they instead both serve to satirise Catholic ideology and evince an intertextual engagement with the wider sociocultural context.

The manner in which Ted plays with issues of gender and sexuality is perhaps the most concerted example of this satirisation. With the Catholic Church occupying a "moral monopoly ${ }^{14 "}$ in post-independence Ireland, vocal on issues of sexual morality and with abortion, contraceptives and divorce all unavailable, the Church's hegemony thus had particular import for women, and the latter decades of the century accordingly saw much feminist resistance to the Catholic ethos of the State, conflicts and discordant ideologies which provide much cultural source material in Father Ted". The episode "Rock-a-hula Ted" (Season 2), for example, opens with Dougal and Ted watching a television show on which rock-star Niamh Connolly (Clare Grogan) appears. Mathews explains that the character of Connolly was "inspired by Sinead O'Connor ${ }^{16 "}$ ", O'Connor's 1994 rap-song "Famine" positing that "there was no famine. See Irish people were

11. Ibid., p. 8.

12. Brett Mills, op. cit., p. 7.

13. Terry Eagleton and Matthew Beaumont, The Task of the Critic: Terry Eagleton in Dialogue, London, Verso, 2009 , p. 239.

14. Tom Inglis, Moral Monopoly: The Rise and Fall of the Catholic Church in Modern Ireland, Dublin, University College Dublin Press, 1998.

15. See Ursula Barry and Clair Wills, "The Republic of Ireland: The Politics of Sexuality 1965-2000”, in Field Day Anthology of Irish Writing: Volume V, Irish Women's Writing and Traditions, ed. Angela Bourke et al., Cork, Cork University Press, 2002.

16. Arthur Mathews and Graham Linehan, op. cit., p. 176. 
only allowed to eat potatoes. All of the other food, meat, fish, vegetables, were shipped out of the country under armed guard to England while the Irish people starved", and in "Rock-a-hula Ted", Niamh Connolly similarly explains that the song she is about to perform is "about how the Church in Ireland secretly had lots of potatoes during the Famine and they hid the potatoes in pillows and sold them abroad at potato fairs... and the Pope closed down a lot of the factories that were making the potatoes and turned them into prisons for children". More significantly for the gender politics of "Rock-a-hula Ted", however, O'Connor also achieved infamy for tearing up a picture of Pope John Paul II on Saturday Night Live in 1992 with the words "Fight the real enemy" and subsequently claiming that the Church had been "beating the shit out of the children for years and sexually abusing them ${ }^{17}$ ", claims which Elizabeth Cullingford notes have been largely vindicated in the years since, and for declaring that "the Catholic Church have controlled us [...] through their teachings on sexuality, marriage, birth control and abortion ${ }^{18 ”}$. As such, O'Connor acts as a readymade cipher for feminist protest against the Church, and in "Rock-a-hula Ted" Connolly, accompanied by a pregnant sign-language interpreter and with an enormous "woman" symbol above her head, accordingly goes on to perform a protest song inveigling against "big men in frocks telling us what to do/they can't get pregnant like I do". Later in the episode she also appears on the cover of music magazine Rock Cupboard - a tribute to Dublin publication Hot Press, of which Mathews was one-time Arts Editor - under the headline "I am still very angry" and wearing boxing gloves emblazoned with "Clit power". Ted, however, is baffled by this slogan, wondering "Clit Power? What does that mean? [...] I used to know a Father Clint Power. Maybe she's having a go at him".

Ted's unfamiliarity with female anatomy is a synecdoche for his obliviousness to feminist concerns at large, not the least of which is the casual subjugation of Mrs Doyle. While watching Connolly on the television, Ted expresses his impatience with "this whole radical feminism lark... this idea that the Catholic Church has some sort of negative attitude towards women" and turns to Mrs Doyle, who has staggered into the room, carrying briquettes. "Mrs Doyle, you're a woman", he says, "what do you think of all this stuff? Do you think the Catholic Church is a bit sexist?" However, he pays scant attention to her response, leaving the room to fetch a packet of crisps for himself and when she has finished talking responds with a cursory and dismissive "yeah, whatever". Furthering the irony is that Mrs

17. Sinead O'Connor, "People Need a Short, Sharp Shock", in Field Day Anthology of Irish Writing: Volume V, Irish Women's Writing and Traditions, op. cit., p. 1619. See also Elizabeth Cullingford, "Seamus and Sinead: From 'Limbo' to 'Saturday Night Live", in Ireland's Others: Gender and Ethnicity in Irish Literature and Popular Culture, Cork, Cork University Press, 2001.

18. Quoted by Elizabeth Cullingford, op. cit., p. 248. 
Doyle had replied "I've always found the Church very responsive to my views. I remember one time I have having terrible troubles at home and the Church gave me great support them. I know a lot of people like to run the Church down but they're just a load of old moaners. Moan, moan, moan. So, thanks for asking Father, but no, no I have no complaints at all". Though Connolly may be a humourless ideologue whose claims are historically garbled, the clergy are nonetheless depicted as indifferent to women's views, with the resulting gender inequity allowing them to watch television while Mrs Doyle whom Eugene O'Brien describes as "the metonym of the role of women in the church ${ }^{19}$ " is engaged in thankless and demanding physical work, her other tasks in the episode including not only vacuuming the parochial house but also digging a draining ditch, retiling the roof, building a greenhouse and washing Ted's car. O'Brien argues that "the value of Father Ted... is to place the structure of the Church in the crucible of satirical commentary. Satire is very much an interrogative discourse in its mode of operation. As it pokes fun at objects, people and structures, it implicitly questions the standards and codes through which these objects, people and structures were accorded value in the first place ${ }^{20 "}$, and "Rock-a-hula Ted" certainly calls into question the degree of the Church's regard for women.

However, Mathews comments of himself and Linehan that "there's no way you could call either of us practising Catholics [...] but we didn't want to make a Sinead O'Connor album ${ }^{21}$ ", and throughout Father Ted the attitude of the clergy towards women is largely one of patronisation rather than outright misogyny. Connolly comes to stay on Craggy Island and Fr Liam, a visiting cleric, exclaims "who's this lovely girl?" He pays no heed to her retort "don't call me a lovely girl, I've sold twenty million records" instead laughing dismissively and his continuing his conversation with Ted. Father Liam is the organiser of the "Lovely Girls" competition, a chaste and sexless beauty pageant which Ted is invited to compere and which is described by Mathews as a "low-budget version of the Rose of Tralee ${ }^{22}$ ". (Such is the cultural currency of Father Ted that the Rose of Tralee is now commonly referred to in popular discourse as a real life "Lovely Girls" contest ${ }^{23}$.) When Ted remarks fondly of one of the contestants, "doesn't Mary have a lovely bottom?", Fr Liam leans across and warns him that this could cause offence. Ted rectifies the situation by declaring "of course, they all have lovely bottoms",

19. Eugene O’Brien, "Kicking Bishop Brennan up the Arse”, in Irish and Catholic? Towards an Understanding of Identity, ed. Louise Fuller, John Littleton and Eamon Maher, Dublin, Columba Press, 2006, p. 47.

20. Ibid., p. 57.

21. Ben Thompson, "In the Name of the Father".

22. Arthur Mathews and Graham Linehan, op. cit., p. 176.

23. Ian O’Doherty, "Sinn Fein Show Their True Colours Again”, Irish Independent, 25 August 2006; Deirdre Reynolds, "I'm Terrified of Stepping into the Shoes of Rose of Tralee Greats", Sun, 19 August 2006; Brendan O’Connor, “The Roses Need a Few More Thorns”, Sunday Independent, 27 August 2006. 
the issue being to avoid any perceived favoritism rather than this sexual objectification and again highlighting Ted's unawareness of feminist issues. Indeed, the sexual dimension to the competition is intentionally muted. According to Fr Liam, choosing a priest as compere "eliminates any sexual aspect" from proceedings in the first place and the participants are subjected less to physical appraisal and more to paternalism and soft-focus sentimentality; dressed in modest belowthe-knee floral frocks, the rounds in which they compete include Lovely Walks, Lovely Laughs and a sandwich-making competition in which their sandwiches must not exceed certain dimensions. In his study of Irish beauty pageants such as the Rose of Tralee and the Calor Housewife of the Year, Fintan Walsh has coined the term "homelysexuality" to describe "a domesticated, marketable, and commer-

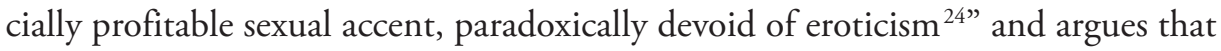
"the Irish pageant has regulated the production of a female sexual accent in particular, emptied of depth, eroticism, or even what might be understood as subjectivity", gender norms which are satirised in "Rock-a-hula Ted".

This diminishment of women as either domestic drudges or delightful but disempowered lovely girls also besets Ted in the episode "Grant Unto Him Eternal Rest" (Season 1). Jack appears to have died after ingesting large amounts of shoe polish and his solicitor, a glamorous young woman, visits the parochial house. After she has detailed the terms of Jack's will to Dougal and Ted, Ted says to her "look, you're a lovely girl, but I really think we should talk to the solicitor". When she emphasises that she is the solicitor, a "senior partner with Corless, Corless and Sweeney", he chuckles and jocularly scolds her for trying to make fun of "the big thickos from the island", Dougal similarly overcoming his customary bashfulness around women to quip that if she's a solicitor then he is Boy George. The following scene opens with Dougal singing "Karma Chameleon" and Ted nursing a black eye, reflecting that "it's true what they say about career girls being very aggressive". Women, under the conservative gender norms satirized in Father Ted, should appear pleasant, make sandwiches and laugh appealingly at Ted's jokes, but not assert their autonomy or assume any sort of responsibility without domesticity.

Furthermore, the downplaying of any sexual dimension to the "Lovely Girls" competition is perhaps attributable to what Tom Inglis describes as "a Catholic culture of self-abnegation in which sexual pleasure and desire were repressed 25 " which "meant instituting separations and divisions between the sexes. It also meant eliminating temptations and what the Church termed

24. Fintan Walsh, "Homelysexuality and the 'Beauty' Pageant”, in Crossroads: Performance Studies and Irish Culture, ed. Sara Brady and Fintan Walsh, Basingstoke, Palgrave Macmillan, 2009, p. 197.

25. Tom Inglis, "Origins and Legacies of Irish Prudery: Sexuality and Social Control in Modern Ireland", EireIreland, 40, n³-4, 2005, p. 11. 
'occasions of sin'. Any place where men and women met socially became problematic ${ }^{26 "}$. Patsy McGarry similarly explains that "told that women were an 'occasion of sin' since the time of Eve, men in Ireland were separated from them in school, at Church and social occasions. They were often frightened of them ${ }^{27}$ ". Dougal is indeed daunted by women, remarking in "Rock-a-hulaTed" that he wouldn't know what to say to "lovely girls" should he find himself in their presence. Ted advises him that suitable topics for conversation include "anything to do with clothes or perfume, basically" and finishes with the encouraging words that "if you ever meet a woman I'm sure you'd been able to deal with it". The segregation of the sexes is such that Ted can speak of "if" Dougal should ever meet a woman, and encountering a woman is configured as a terrifying experience with a ferocious species entirely different to oneself, similar perhaps to meeting a bear in the wild.

Similarly, when Polly Clark, an attractive novelist, pays a visit to the parochial house in the episode "And God Created Woman" (Season 1), Dougal hides behind the sofa rather than engage in conversation with her, later explaining to Ted "I don't know many women". When Ted points out that his mother is a woman, Dougal responds "My mother? She's not really a woman, Ted. She's not like the women you see on the telly. Like the Gladiators. She wouldn't be one of them". Ted must concede that Dougal's mother would indeed bear little resemblance to the leotard-clad contestants on Gladiators, a physical combat entertainment show, and so points to Mrs Doyle as another example of a woman, at which point Dougal gives him an incredulous look and says "ah come on now Ted". "Woman", Monique Wittig contends in The Straight Mind, "is an imaginary formation and not a concrete reality 28 " and "woman" likewise operates here less a biological category than as cultural construct, "women" being defined by and subsequently feared for their sexuality. Indeed, while it is unlikely that Ted and Dougal are familiar with Wittig's work, they also corroborate her contention that "woman' has meaning only in heterosexual systems of thought ${ }^{29}$ ". "Aren't nuns great though Ted?" Dougal says with relief in "Grant Unto Him Eternal Rest", "it's good because you feel as nervous with them as you do with real women". Similarly, when Jack's solicitor arrives at the parochial house and Mrs Doyle tells Ted "there's a woman here to see you", he corrects her; "a woman, Mrs Doyle? You mean a nun". Wittig argues that lesbians, having stepped outside the realm of heterosexuality, are not "women", "for what

26. Ibid., p. 21-22.

27. Patsy McGarry, "The Rise and Fall of Roman Catholicism in Ireland", in Irish and Catholic? Towards an Understanding of Identity, op. cit., p. 38-39.

28. Monique Wittig, The Straight Mind and Other Essays, Boston, Beacon Press, 1992, p. 59.

29. Ibid., p. 32. 
makes a woman is a specific social relation to a man [...] a relationship which implies personal and physical obligation as well as economic obligation [...] a relation which lesbians escape by refusing to become or to stay heterosexual ${ }^{30}$ " and nuns are similarly not considered "women" in Father Ted, located as they are "beyond the categories of $\operatorname{sex}^{31}$ ".

Mrs Doyle, however, is unwavering that the solicitor is "a woman", "a young woman. With a skirt" she adds disapprovingly. Gerardine Meaney argues that "the attractions of the traditional feminine role, particularly as the Catholic Church defines it, are grounded in a deep loathing of femininity [...] and those women who identify with it are also expressing a form of self-hatred, a revulsion against themselves as women ${ }^{32}$ ". For Mrs Doyle, champion as she is of the Church, this loathing of femininity is manifested in both the suppression of her own sexual energies and an antagonism towards those women who do not follow suit, Mathews remarking that she "deeply distrusts any woman who isn't a nun and doesn't have a mole and a moustache ${ }^{33}$ ". When Polly Clark visits the parochial house she too is met with a hostile reception from Mrs Doyle, who addresses the novelist brusquely, remains stony faced when she and Ted share a joke, and later comments purse-lipped to Ted "I never thought we'd have anyone like her staying here". She also expresses her disappointment at Ted's enjoyment of Clark's work, remarking "I'm surprised at that, Father. I didn't think you'd like that sort of thing. I read a bit of one of them once. God, I couldn't finish it. The language $[\ldots]$ unbelievable $[\ldots]$ it was a bit much for me, Father". However, she is suspiciously familiar with Clark's books in light of this alleged repudiation of them. Arms folded in displeasure, she quotes from them at length:

Feck this and feck that... You big bastard... Oh dreadful language. You big hairy arse. You big fecker. Fierce stuff. And of course, the F word Father. The bad $\mathrm{F}$ word. Worse than feck. You know the one I mean. F you. F your effing wife. I don't know why they have to use language like that. I'll stick this effing pitchfork up your hole, that was another one. Bastard this and bastard that. You can't move for the bastards in her books. It's wall-to-wall bastards. You bastard. You fecker. You bollocks. Get your bollocks out of my face. God it's terrible Father.

So engrossed does she become in her tirade that even being forcibly escorted from the room by Ted does not deter her, instead shouting back from off-set "ride me sideways, that was another one". Mathews describes this side of

32. Gerardine Meaney, Sex and Nation: Women in Irish Culture and Politics, Dublin, Attic Press, 1991, p. 189.

33. Arthur Mathews and Graham Linehan, op. cit., p. 64. 
Mrs Doyle's character as "a kind of suppressed sexual obsession masquerading as

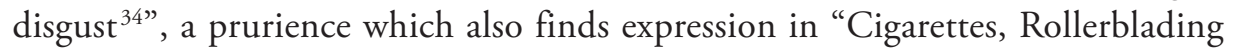
and Alcohol" (Season 2) when she describes a couple whom she encountered the year before:

They were a bit obsessed with the old... S-E-X. God I'm glad I never think of that type of thing Father. That whole sexual world. God, when you think of it it's a dirty, filthy thing, isn't it Father? Can you imagine Father? Can you imagine Father, looking up at your husband, and him standing over you with his lad in his hand, wanting you to degrade yourself? God almighty can you imagine that Father? Can you picture it there Father? Oh get a good mental picture of it. Can you see him there? Ready to do the business?

As when describing Clark's novels, Mrs Doyle becomes extremely animated on the topic of "that whole sexual world", leaning closer and closer into Ted's face as she attempts to illuminate the scene for him and the graphicism of her descriptions somewhat undercutting her claims that she never thinks about "that type of thing". Mrs Doyle's simultaneous obsession with and denunciation of sex as a "dirty, filthy thing" can be understood as the return of the repressed emanating from what Eugene O'Brien describes as "a culture where repression of desire was very much part of the socio-religious mindset ${ }^{35 " . ~ P a t s y ~ M c G a r r y ~ d e s c r i b e s ~ h o w ~ i n ~}$ post-Famine Ireland:

Sex became taboo. Allied to a Victorian prudery rooted in an eighteenth century wave of evangelical revivalism in Britain, and a Catholic Church seemingly fixated on sex as the only sin, sensuality was suppressed in the Irish consciousness [...] In 1854 Pius IX promulgated the Doctrine of the Immaculate Conception and the clergy preached that celibate life was superior to married life, that "impure thought" was evil, as was all sexual activity without a marriage licence. Sexual pleasure was taboo. It was commonly described as "dirty", "disgusting", powerful evidence of an inferior animal nature which constantly threatened what was divine in the human ${ }^{36}$.

Additionally, Inglis also observes that "the denial and silencing of sex" did not exist in isolation but instead formed "part of a wider cultural programme of denying and sacrificing the self ${ }^{37}$ ". In "A Christmassy Ted" (Season 2), Mrs Doyle

\section{Ibid.}

35. Eugene O’Brien, "Kicking Bishop Brennan up the Arse”, op. cit., p. 47.

36. Patsy McGarry, "The Rise and Fall of Roman Catholicism in Ireland", op. cit.

37. Tom Inglis, "Origins and Legacies of Irish Prudery: Sexuality and Social Control in Modern Ireland", op. cit., p. 24. 
is aghast to learn of an automated Teamaster machine which "takes the misery out of making tea". "Maybe I like the misery" is her bristly response. Likewise, in "Cigarettes, Alcohol and Rollerblading", she sets out upon a pilgrimage to St Patrick's Hill and stops Ted short when he describes the experience as "tremendous fun $[\ldots]$ you don't wear socks and then they chase you with a big plank", saying that she wants a "good miserable time" instead. St Patrick's Hill is a thinly fictionalised version of Croagh Patrick, a hill in County Mayo which penitents traditionally climb barefoot on the last Sunday in July, and "Cigarettes, Alcohol and Rollerblading" is adroit in amplifying and parodying what Inglis identifies as the "strong element of self-denial and penitential practice in Irish Catholicism ${ }^{38}$ ". The episode takes its name from the vices which Ted, Jack and Dougal are respectively prevailed upon by a neighbouring cleric to give up for Lent, but they soon lapse in this, leading Ted to compares themselves disfavourably to the figure of Matty Hislop, "a drunkard who found God and punished himself for his sins. He did all kinds of things. He had this terrible allergy to cats so he used to carry a kitten in his pocket and sniff it from time to time. His head just inflated like a balloon". Ted rings the "Matty Hislop crowd" for assistance with their Lenten abstinence and Sister Assumpta is dispatched to the parochial house. She subjects Dougal and Ted to a "daily punishment" such as dragging them along the ground behind a tractor, replacing their mattresses with bricks, immersing them in icecold baths, and chivvying them to "get an early start or we'll miss the rain". Inflicting hardships such as these upon oneself, she explains, is part of "Matty Hislop's ten-step programme to rid yourself of your pride". Sr Assumpta promulgates "a disdain for and detachment from materialism, that is, seeking satisfaction through involvement in the world, particularly through material comforts, consumer products and sensuous pleasures ${ }^{39}$ ". Ted, however, simply feels that she's "obviously insane". Mathews similarly explains that Hislop is based on Matt Talbot - a Dubliner who in late nineteenth and early twentieth century atoned for his years of alcoholism through extreme masochism and self-denial, practicing mortification of the flesh and devoting almost unfeasible amounts of time to prayer - and remarks of Talbot, "nowadays he'd be considered mad and given psychiatric help but in Dublin there's a bridge and a street named after him ${ }^{40}$ ". As Inglis notes, "the rejection of enjoyment, pleasure and desire obtained enormous cultural kudos $^{41}$ " while the Church reigned hegemonic, but in a changed cultural climate such asceticism now appears comic and alarming in equal parts.

38. Tom Inglis, Global Ireland: Same Difference, London, Routledge, 2008, p. 3.

39. Ibid., p. 146.

40. Arthur Mathews and Graham Linehan, op. cit., p. 190.

41. Tom Inglis, "Origins and Legacies of Irish Prudery: Sexuality and Social Control in Modern Ireland", op. cit., p. 24. 
Just as how the ascetic tradition is implicitly undermined in this fashion, so too are Catholic social teachings subverted in Father Ted through the juxtaposition of mores and norms. In "Song for Europe" (Season 2), for example, Dougal and Ted enter a song contest and Charles, the producer of the show, explains that he is in a gay relationship. Ted is taken aback but attempts to cover his surprise with jovial liberalism, introducing Dougal as his own partner, then clarifying "not my sexual partner! I mean, you know, my partner that I do the song with... not that there's anything wrong with that type of thing". Charles' stony response is to inquire "I thought the Church thought that 'that type of thing' was inherently wrong?” After all, the Catholic Catechism denounces homosexual acts as "intrinsically disordered [...] contrary to the natural law [...] under no circumstance can they be approved", while the 1986 "Letter to the Bishops of the Catholic Church on the Pastoral Care of Homosexual Persons" by the then Cardinal Ratzinger (now Pope Benedict XVI) similarly describes homosexual inclination as a "strong tendency ordered towards an intrinsic moral evil ${ }^{42}$ ". Ted, however, prevaricates around such condemnation:

Ah, yes. It does. The whole gay thing: I suppose it's a bit of a puzzle to us all. I suppose it must be great fun though - not the, eh, you know but the nightclub scene and all that. The whole rough and tumble of - of homosexual activity and having boyfriends when you're a man. Anyway, don't worry about what the Church thinks! Sure they used to think the earth was flat! It's like, you know, sometimes the Pope says things he doesn't really mean. You know. We all get things wrong. Even the Pope!

Charles then asks "what about papal infallibility?", leaving Ted truly trumped and Catholic moral thinking destabilized through this role reversal whereby the priest endorses social liberalism while his gay parishioner instead draws attention to articles of faith. While Ted's bumbling might be an example of the "recognisable, stock situations ${ }^{43}$ " that sitcom customarily uses as the base of its comedy, the incident also serves to isolate and undercut traditional Church teaching.

The Church's rigid opposition to contraceptives also becomes comic fodder in Father Ted, a dissonance again existing between Ted's instinctive response to a situation and the position he is impelled to adopt as part of the Catholic hierarchy. In "Speed 3" (Season 3), he suspects that Pat Mustard, a hirsute lothario

42. Catechism of the Catholic Church, Part 3: Section 2: Chapter 2: Article 6, [http://www.scborromeo.org/ccc/ p3s2c2a6.htm\#2357] (accessed December 29, 2011); "Letter to the Bishops of the Catholic Church on the Pastoral Care of Homosexual Persons", [http://www.vatican.valroman_curia/congregations/cfaith/documents/ rc_con_cfaith_doc_19861001_homosexual-persons_en.html] (accessed December 29, 2011).

43. Terry Lovell, quoted in Brett Mills, The Sitcom, op. cit., p. 1. 
milkman, "has been delivering more than dairy products" on his morning rounds, leading to a slew of "very hairy babies" across Craggy Island. When Ted calls Pat to task over this, however, Pat denies any responsibility, saying "you need proof for that kind of accusation, Father. And I'm a very careful man, Father. A very careful man". Ted's indignant retort is "except when it comes to taking precautions in the bedroom", to which Pat's sly rejoinder is "you wouldn't be advising the use of artificial contraception, would you Father?" Indeed, the Church's position as declared in Humane Vitae is to unequivocally oppose "any action which either before, at the moment of, or after sexual intercourse, is specifically intended to prevent procreation ${ }^{44}$ ", leaving Ted's only recourse being to tell Pat Mustard to “just... feck off”. Similarly, in "Kicking Bishop Brennan Up the Arse" (Season 3), Ted has a nightmare in which he is sent to a remote jungle to attempt to convert a tribe of warriors to Catholicism. However, they remain unconvinced and, as they are about to sacrifice Ted to their Volcano God, one of them remarks of Catholicism "it'll never catch on here. We don't agree with the Pope's line on artificial contraception. It's the 1990s, for goodness sake", even an animistic jungle-tribe thereby being more progressive in matters of sexual morality than is the Catholic Church.

Before being cast in the titular role of Father Ted, actor Dermot Morgan had long been antipathetic towards the Catholic Church in his stand-up routines, as well garnering a reputation as a keen satirist for Scrap Saturday, a radio programme broadcast on RTÉ Radio One in the early Nineties and on which he was the main performer ${ }^{45}$. Aware of his reputation as an iconoclast, he remarked of Linehan and Mathews that "the guys always say disingenuously if you ask me that [Father Ted]'s just a happy show about priests [...] But anything so deranged has to have a subversive element $[\ldots]$ for all their protestations of innocence, the fact that they'd hire me at all shows their true intent. It's like saying, 'We're setting up a general practice. Let's get Dr Mengele in' ${ }^{\prime 6}$ ". Though Father Ted may have initially have been broadcast on a British television network and though British sitcom may have acted as so formative an influence for Linehan and Mathews, the appearance of Morgan in Ted would thus have been for an Irish audience that is to say, an audience attuned to the show's fuller cultural context just one of the many signifiers of Ted's more antagonistic treatment of the Catholic Church than Linehan and Mathews' stance on the programme allows for. The comic absurdity which is the keynote of Ted is far from equating with cultural obliviousness; often

44. Pope Paul VI, "Encyclical Letter Humanae Vitae", [http://www.vatican.va/holy_father/paul_vilencyclicals/documents/hf_p-vi_enc_25071968_humanae-vitae_en.html] (accessed December 29, 2011).

45. Dermot Morgan, Trendy Sermons, Ward River Press, Dublin, 1981 ; Dermot Morgan et al., Scrap the Collection, Dublin, Lunar Records, 2002.

46. James Rampton, "Altar Egos of the Sitcom", Independent, 1 March 1996. 
it is the hierarchy and the "Catholic culture based on practises of chastity, humility, piety and self-denial ${ }^{47}$ " which appear most absurd of all. Not only that, but through the use of stereotypes and set-pieces, the sitcom format facilitates rather than hinders this underlying critique.

47. Tom Inglis, Global Ireland: Same Difference, op. cit., p. 3. 